\title{
THEORY AND DEVELOPMENT OF A VRI DECISION SUPPORT SYSTEM: THE USDA-ARS ISSCADA APPROACH
}

\author{
S. R. Evett, S. A. O'Shaughnessy, M. A. Andrade, P. D. Colaizzi, \\ R. C. Schwartz, H. S. Schomberg, K. C. Stone, E. D. Vories, R. Sui
}

Beyond 2020,

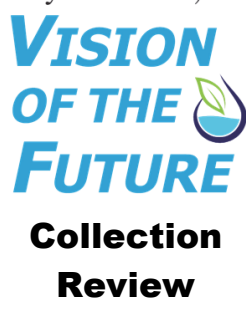

\begin{abstract}
HighLIGHTS
- Multi-faceted research efforts converged to an automated irrigation decision support system (DSS).

- Low-cost, solar-powered, wireless plant abiotic and biotic stress sensors were developed to aid the DSS.

- Low-cost, accurate TDR soil water sensors and a wireless node and gateway system were developed for the DSS.

- Sensor systems and research-based algorithms were integrated into an automated irrigation DSS and control system.
\end{abstract}

\begin{abstract}
Variable-rate irrigation (VRI) is now possible with every new center pivot irrigation system sold, either using sector (speed) control or both sector and zone (radial along the pipeline) control. However, decision support systems able to generate a prescription for spatially varying irrigation based on crop water need have lagged far behind VRI equipment. Irrigation based on crop water need has been shown to increase both crop water productivity and nutrient use efficiency, meaning that an effective VRI decision support system (DSS) could improve profitability while conserving resources. In this article, we report separately on a VRI DSS using sensor-based plant and soil water feedback as implemented in four U.S. states. This article describes the genesis and development of the Irrigation Scheduling Supervisory Control and Data Acquisition (ISSCADA) system, of the integral plant and soil sensors, and of its wireless sensor network subsystems, as well as the role of multi-location research efforts and cooperative research and development agreements in the development of the needed plant and soil sensors and the ISSCADA and wireless sensor network systems.
\end{abstract}

Keywords. Crop water productivity, Decision support system, Product development, Sensors, Variable-rate irrigation, VRI.

\footnotetext{
(c) (1) $\ominus$ The authors have paid for open access for this article. This work is licensed under a Creative Commons AttributionNonCommercial-NoDerivatives 4.0 International (CC BY-NC-ND 4.0) license https://creative commons.org/licenses/by-nc-nd/4.0/).

Submitted for review in January 2020 as manuscript number NRES 13922; approved for publication as an Invited Review and as part of the National Irrigation Symposium 2020 Collection by the Natural Resources \& Environmental Systems Community of ASABE in April 2020.

Mention of company or trade names is for description only and does not imply endorsement by the USDA. The USDA is an equal opportunity provider and employer.

The authors are Steven R. Evett, Research Soil Scientist, and Susan A. O'Shaughnessy, Research Agricultural Engineer, USDA-ARS Conservation and Production Research Laboratory, Bushland, Texas; Manuel A. Andrade, Assistant Professor, Department of Agriculture, Veterinary, and Rangeland Sciences, University of Nevada, Reno, Nevada; Paul D. Colaizzi, Research Agricultural Engineer, and Robert C. Schwartz, Research Soil Scientist, USDA-ARS Conservation and Production Research Laboratory, Bushland, Texas; Harry S. Schomberg, Ecologist, USDA-ARS Sustainable Agricultural Systems Laboratory, Beltsville, Maryland; Kenneth C. Stone, Research Agricultural Engineer, USDA-ARS Coastal Plain Soil, Water, and Plant Conservation Research Unit, Florence, South Carolina; Earl D. Vories, Research Agricultural Engineer, USDA-ARS Cropping Systems and Water Quality Research Unit, Columbia, Missouri; Ruixiu Sui, Research Agricultural Engineer, USDA-ARS Sustainable Water Management Research Unit, Stoneville, Mississippi. Corresponding author: Steven R. Evett, USDA-ARS, 300 Simmons Road, Unit 10, Bushland, TX 79012; phone: 806-356-5775: email: steve.evett@usda.gov.
}

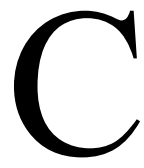
enter pivot irrigation systems currently serve $>57 \%$ of irrigated lands in the U.S. (USDANASS, 2019). Every new center pivot irrigation system sold today has some ability to apply variable-rate irrigation (VRI), either using sector (speed) control or both sector and zone (radial along the pipeline) control. However, there is a lack of decision support systems (DSS) able to generate prescriptions for spatially varying irrigation based on crop water need as it changes in time and space. Irrigation based on crop water need has been shown to increase both crop water productivity (CWP) and nutrient use efficiency, meaning that an effective VRI DSS could improve profitability while conserving resources used per unit of economic production. A key problem with irrigation scheduling in general is that when one schedule is applied to an entire field it can leave part of the field over-irrigated and part of the field under-irrigated, with potential yield and input use efficiency declines in both cases. These declines can be exacerbated if deficit irrigation is attempted because the under-irrigated parts of the field will suffer even more, making deficit irrigation a risky proposition. A VRI DSS should be able to respond to site-specific crop water needs, thus avoiding creation of under- and over-irrigated field areas, which would allow effective application of uniform deficit irrigation that will typically result in greater crop water 
productivity as well as acceptable crop yields. Greater CWP and yield with deficit irrigation was illustrated for sorghum by Evett et al. (2013) (fig. 1a). Sorghum deficit irrigation trials using irrigation algorithms based on canopy temperaturebased indices [the time-temperature threshold (TTT) index and the integrated crop water stress index (iCWSI) will be explained subsequently] indicated that larger crop water productivities could be obtained for deficits in the $50 \%$ to $80 \%$ of full irrigation range when compared with either full irrigation or dryland production (fig. 1b).

More recently, an Irrigation Scheduling Supervisory Control and Data Acquisition (ISSCADA) system was patented (Evett et al., 2014a) by the USDA-ARS and licensed by Valmont Industries. Several reports have described the
ISSCADA software and its ability to integrate data from wireless plant canopy, soil water, and weather sensors (Andrade et al., 2015, 2016, 2017) (fig. 2), as well as application of the system to apply well-regulated and safe deficit irrigation and thus increase CWP with several crops (O'Shaughnessy et al., 2015, 2016a, 2017, 2018a).

In this article, we discuss the theoretical and practical background of plant- and soil-based irrigation scheduling algorithms, the development of sensors and wireless sensor networks needed for practical application of a VRI DSS, the commercialization of sensors and sensor networks, and the integration of these into the ISSCADA system for VRI DSS. Andrade et al. (2020a, 2020b) discuss the most recent ISSCADA software development and application.
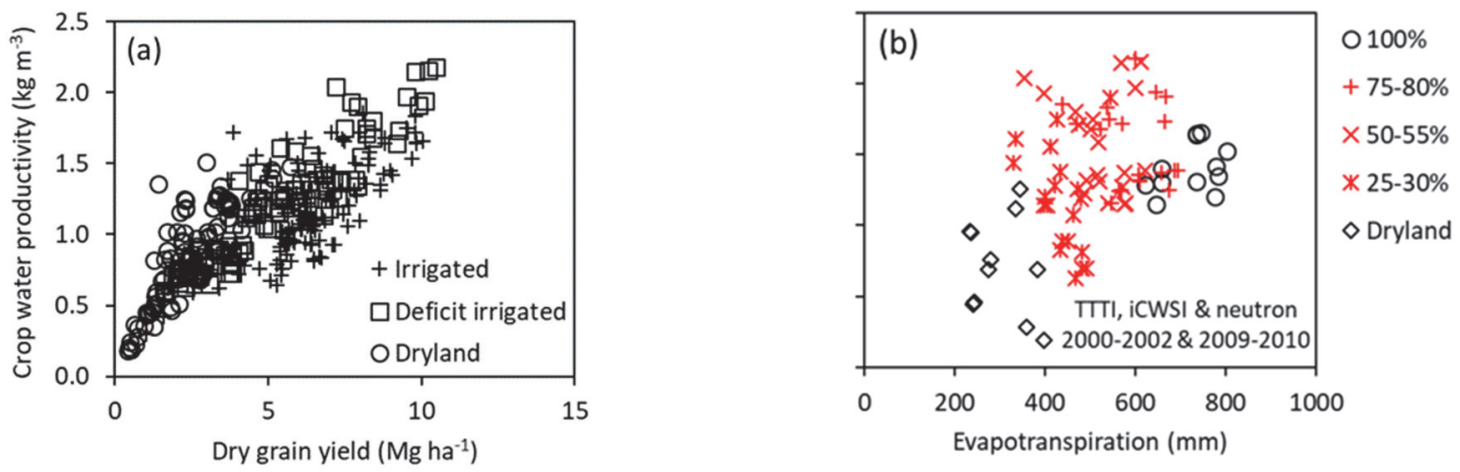

Figure 1. (a) Sorghum crop water productivity versus yield for full irrigation $(+)$, deficit irrigation $(\square)$, and dryland practices $(\circ)$. Data are for 352 treatment years between 1960 and 2010 on soils in the Texas Panhandle and Kansas (Evett et al., 2013). (b) Comparison of crop water productivity versus water used (evapotranspiration). Data are for sorghum managed using automated deficit irrigation and for sorghum managed as dryland (no irrigation) and with full irrigation $(\mathbf{1 0 0 \%})$ based on neutron probe readings. The time-temperature threshold index (TTTI) and integrated crop water stress index (iCWSI) were used as algorithms for automated deficit irrigation. Data are for 83 treatment years (Evett et al., 2013).

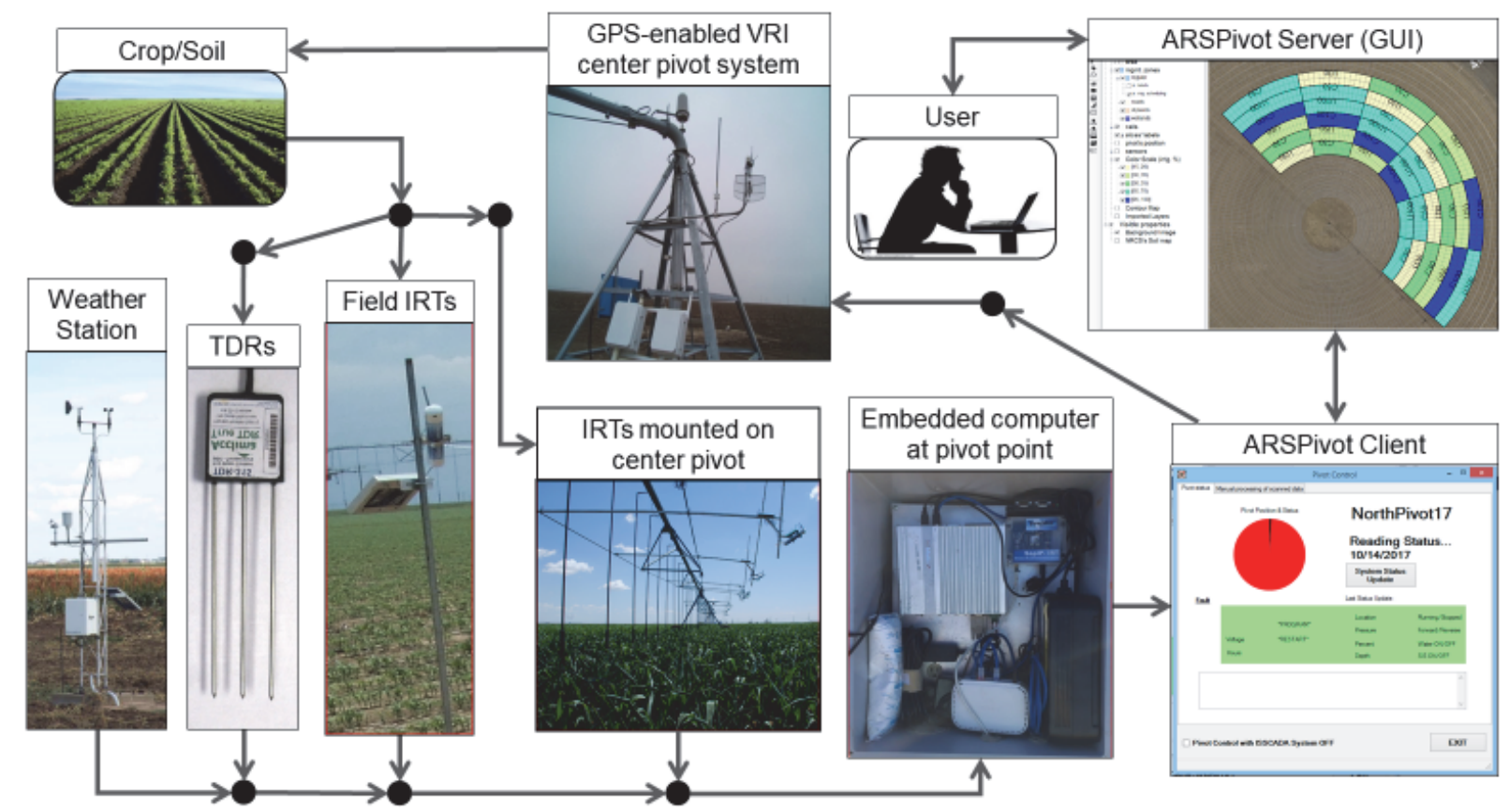

Figure 2. Illustration of the ISSCADA system as presented by Andrade et al. (2018). Crop water stress is sensed by infrared thermometers (IRTs) mounted on the moving center pivot lateral and in a fixed position in the field, soil root zone water status is sensed by TDR soil water sensors in the field, and weather (wind speed, solar irradiance, air temperature, humidity and precipitation) is sensed nearby. All data are telemetered wirelessly to the embedded computer at the pivot point, which runs the ARSPivot software client, the heart of the ISSCADA system. The client gathers data throughout the day, calculates water stress indices, and communicates them to the ARSPivot software server, where they are displayed in a graphical user interface (GUI) along with an irrigation prescription map. The user alters the map or accepts it as is, and then clicks on an icon to send the prescription to the center pivot control panel, where it is used to apply variable-rate irrigation. 


\section{BACKGROUND SCIENCE AND TECHNOLOGY}

Advances in the science and technology of plant and soil water sensing were necessary before a sensor-based irrigation scheduling system could be automated reliably, relatively inexpensively, and with minimal interference with farming operations in the field. Previous sensing technologies were expensive, often manually operated or requiring extensive wiring that was incompatible with field operations, often inaccurate, and expensive to maintain.

\section{Canopy and Leaf Temperature Sensing}

The relationships between soil water status, crop canopy temperature and crop water stress were studied by Clark and Hiler (1973), Ehrler (1973), and by Jackson et al. (1981) at the USDA-ARS Water Laboratory in Tempe, Arizona, and elsewhere in the 1970s and 1980s, as summarized by Jackson (1982). The understanding that crop water stress is related to soil water status is age old, which is why irrigation has been part of human endeavor for several thousand years (Evett et al., 2020), but the relationships between soil water status, plant water stress as indicated by leaf and stem water potentials, and crop leaf and canopy temperatures were not well explored prior to the development in the 1960s of portable, infrared thermometers (IRTs) with bandpass filters in the 8 to $13 \mu \mathrm{m}$ range (Fuchs and Tanner, 1966).

Jackson (1982) summarized earlier research, including that done at the USDA-ARS Water Laboratory prior to 1982. Ehrler (1973) found an inverse relationship between the leafair temperature difference (temperature of leaf minus temperature of air) and vapor pressure deficit. Clark and Hiler (1973) found leaf-air temperature difference to be complicated by solar irradiance level and less directly indicative of plant water stress. Idso and Baker (1967) concluded that reradiation and sensible heat flux were the major mechanisms of energy transfer for individual sunlit leaves, but cooling by transpiration dominated the energy balance for the canopy as a whole. This meant that if a reduction in transpiration is an indicator of plant water stress, then canopy temperature measurements were more indicative of stress than individual leaf measurements. Jackson et al. (1977) and Idso et al. (1977) defined an index called the stress degree day (SDD) as the difference between the canopy and air temperatures at midday. Plotting the accumulative SDD alongside water depleted from the root zone indicated a relationship (fig. 3a), as did plotting total water used versus SDD (fig. 3b). Although the relationships for winter wheat were suggestive, applying the SDD concept to corn did not confirm the relationship (Gardner, 1981a). Several studies revealed relationships between leaf water potential and canopy-air temperature difference (Ehrler et al., 1978a, 1978b; Gardner et al., 1981b), but the relationships were not stable.

Jackson et al. (1981) and Idso et al. (1981a, 1981b) developed a crop water stress index (CWSI). They considered the energy balances of non-stressed and completely stressed crop canopies where the canopy resistance $\left(r_{c}\right)$ of a nonstressed crop would be zero and that of a completely stressed crop would approach infinity $(\infty)$. Considering that the aerodynamic resistance $\left(r_{a}\right)$ also affects transpiration rate and leaf energy balance, they wrote the Penman-Monteith energy balance equation for actual latent energy $(E)$ for any values of $r_{a}$ and $r_{c}$ and for potential latent energy $\left(E_{p}\right)$ when $r_{c}=0$ and took the ratio $E / E_{p}$ as an index that varies from 0 for a completely water-stressed canopy (no transpiration) to unity for a well-watered crop. For "esthetic" reasons, they defined the CWSI as follows:

$$
\begin{aligned}
\text { CWSI } & =1-E / E_{p} \\
& =\frac{\gamma\left(1+r_{c} / r_{a}\right)-\gamma^{*}}{\Delta+\gamma\left(1+r_{c} / r_{a}\right)}
\end{aligned}
$$

where $\gamma$ is the psychrometric constant $\left(\mathrm{Pa}^{\circ} \mathrm{C}^{-1}\right), \gamma^{*}$ is equal to $\gamma\left(1+r_{c p} / r_{a}\right), r_{c p}$ is the canopy resistance at "potential evaporation" (which may vary with species and variety), and $\Delta$ is the slope of the saturated vapor pressure-temperature relationship $\left(\mathrm{Pa}^{\circ} \mathrm{C}^{-1}\right)$.

The CWSI is written as CWSI $=1-E / E_{p}$ so that the CWSI equals unity for a completely water-stressed crop (no transpiration); when $r_{c} \rightarrow \infty$, the value of $E$ approaches zero and the ratio $E / E_{p}$ approaches zero so that the CWSI approaches unity. Additional complexities arise when considering the value of $\Delta$ at canopy and at air temperature; approaches for resolving these complexities are given by Jackson (1982).

Jackson et al. (1981) explored the relationship between CWSI and relative amounts of extractable water used by a
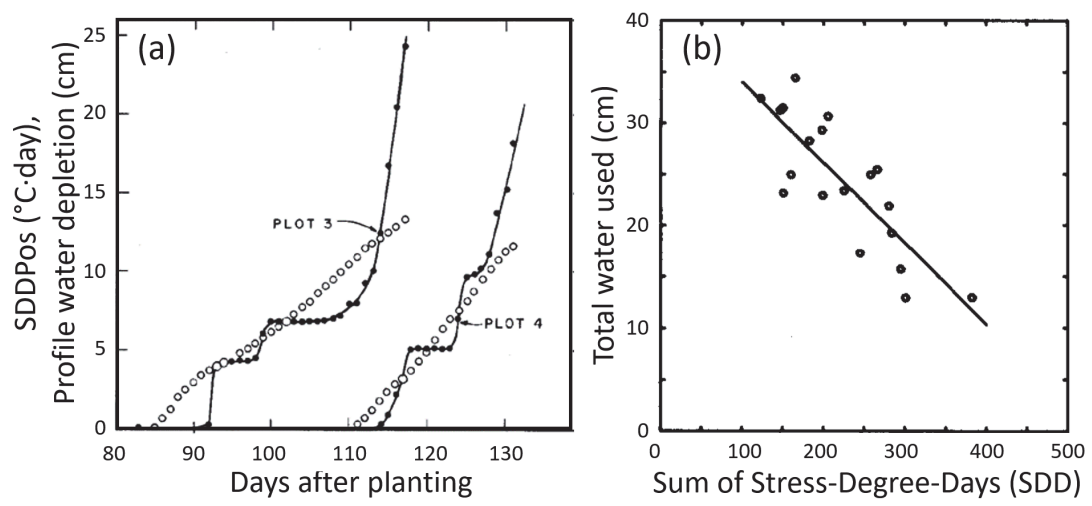

Figure 3. (a) Accumulated positive stress degree days (SDDPos) (black circles) plotted with soil profile water depletion (open circles) for winter wheat versus days after planting in two irrigated plots (Jackson et al., 1977), and (b) total water used by winter wheat versus accumulated SDD. Redrawn by Jackson (1982) from figure 5 of Walker and Hatfield (1979); adapted from Jackson (1982). 
wheat crop in Arizona. Although they found a correspondence between the two, there was a recovery period after irrigation that indicated that plant physiological changes, including root response, mediated the relationship. Further exploration revealed that the relationship between soil water and CWSI was not unique and likely depended on irrigation, root growth, and senescence histories during a season. Barnes et al. (2000) found only a weak correlation $\left(r^{2}=0.39\right)$ between the CWSI of a cotton crop in Arizona and the percent depletion of available soil water. Colaizzi et al. (2003b) studied a modified form of the CWSI called the water deficit index (WDI) and found relatively weak correlations with fractional soil water depletion under high-frequency sprinkler irrigation of cotton in Arizona, but they found stronger relationships between CWSI and soil water depletion for conditions of low-frequency surface irrigation (Colaizzi et al., 2003a). Working with sunflower, Taghvaeian et al. (2014) found that CWSI and another index, DANS (degrees above non-stressed baseline), were unrelated to soil water deficit ( $\mathrm{mm}$ less than total available root zone water) until a deficit $>90 \mathrm{~mm}$ was reached, which they considered to be the management allowed depletion for their conditions. DeJonge et al. (2015) examined correlations between six canopy temperature-based indices, including CWSI and DANS, and soil water deficit in a corn field and found weak correlations $\left(\mathrm{r}^{2}=0.320\right.$ for DANS and $\mathrm{r}^{2}=0.319$ for CWSI) and considerable scatter. Late in a cotton growing season during which four levels of irrigation were applied, CWSI values were well correlated with soil profile water content at Bushland, Texas (Evett et al., 2014b). However, Evett et al. (2016) found relatively weak correlations between a daily integrated CWSI and fractional available soil water content in the root zone of corn, and the relationships also changed during the season. They suggested that a soil water potentialbased index might be better correlated with CWSI than was the fractional available soil water content.

At Bushland, Texas, Howell et al. (1986) measured canopy temperatures of winter wheat at different phenological stages and calculated the CWSI, which had some dependence on phenology. However, they concluded that the CWSI should be useful for scheduling sprinkler irrigation of winter wheat. The CWSI was used by a few irrigators in Arizona and elsewhere to manage irrigation, but it remained mostly in the research sphere despite the availability of hand-held IRTs. The empirical CWSI (eCWSI) approach of Idso et al. (1981a) required measurements of humidity and temperature of the air as well as canopy temperature, but it encountered problems related to interference from net radiation and wind speed variations. Jackson et al. (1988) reviewed the early history of the CWSI and problems related to its use; they proposed some changes to the theoretical approach as well as methods for estimating the aerodynamic and canopy resistances required in the theoretical CWSI of Jackson et al. (1981). Nielsen (1990) applied the empirical CWSI to soybeans and found that the unstressed baseline developed elsewhere (Manhattan, Kansas, and Fargo, South Dakota) did not apply to conditions at Akron, Colorado. He concluded that a location-specific non-stressed baseline should be developed by researchers and producers wanting to use the empirical CWSI.
Gardner et al. (1992a) reviewed problems with application of the empirical CWSI and listed causes of values outside the expected range as: (1) difficulty in determining the non-water-stressed baseline due to variations in solar radiation, wind speed, air temperature and humidity (vapor pressure deficit), and crop phenology and physiology; (2) evaporation from wet plant surfaces after rain, dew, or irrigation; (3) reduced solar irradiance due to clouds, haze, or IRT measurements taken more than $2 \mathrm{~h}$ before or after solar noon; (4) excessive wind speed; (5) IRT measurements of shaded leaves rather than sunlit leaves; (6) unusually cool or hot air temperatures; (7) poor aiming of the IRT that included soil in the view; and (8) an incorrect non-water-stressed baseline. They suggested that two to three cropping seasons of data were required to establish a reliable baseline. A follow-on article (Gardner et al., 1992b) provided guidance for IRT use (condition, configuration, position, aiming, and view of the crop) and for measurement of air temperature and humidity, wind speed, and solar irradiance, including time of day for measurements. Despite much research and excellent guidance, the CWSI remained little used in irrigation management outside of research, perhaps due to the complexities revealed by Gardner et al. (1992a, 1992b) and others, and perhaps due to the fact that the method remained largely manual in implementation.

An alternative to the CWSI arose from the work of Mahan et al (1987) and Burke et al. (1988), who described a "thermal kinetic window" to be the temperature range within which plant physiology was most productive. Mahan and Upchurch (1988) hypothesized a limited homeothermy by which plants use mechanisms (mainly transpiration) to prevent leaf temperature from becoming much greater than this range and confirmed this hypothesis for cotton (Upchurch and Mahan, 1988). Burke et al. (1990) used the crop-specific optimum temperature (mid-point of the thermal kinetic window) as a baseline temperature to define a thermal stress index (TSI):

$$
\mathrm{TSI}=\left[\left(T_{f}>T_{b}\right)-T_{b}\right] / T_{b}
$$

where $T_{f}$ is the canopy temperature, and $T_{b}$ is the base line temperature $\left(27.5^{\circ} \mathrm{C}\right.$ for cotton).

They showed that the TSI increased more slowly for irrigated than for non-irrigated cotton, that temperature of fully expanded leaves tended to remain at or below $T_{b}$ for irrigated cotton, and that the TSI was well correlated with the CWSI $\left(\mathrm{r}^{2}=0.92\right)$. The first report of using the TSI to manage irrigation was in 1988 (Wanjura et al., 1988). Wanjura et al. (1990, 1992) called $T_{b}$ the canopy temperature threshold and used three threshold values to irrigate cotton, demonstrating that deficit irrigation and crop water productivity could be regulated and that drip irrigation scheduling could be automated on a 15 min decision interval using the method, although the study was not replicated. In another non-replicated study, Wanjura et al. (1995) expanded the TSI algorithm to include a time threshold, resulting in the temperature-time-threshold (TTT) algorithm that could be used for daily irrigation decision intervals such as might be useful for a center pivot irrigation system. The TTT index was the time accumulated during a day whenever the canopy temperature was greater than the temperature threshold. Time was not accumulated if the 
wet bulb temperature was greater than the threshold temperature minus $2^{\circ} \mathrm{C}$ because humidity can limit evaporative cooling. A crop-specific time threshold was determined as the average number of minutes in a day during the irrigation season that the canopy temperature was greater than the temperature threshold for a well-watered crop. This irrigation management system based on an optimal leaf temperature for enzyme activity (the temperature threshold) and a climate- and crop-dependent time threshold was patented by Upchurch et al. (1996). In a replicated study at Bushland, Texas, Evett et al. $(1996,2000)$ demonstrated that automatic drip irrigation using the TTT method was more responsive to corn stress than was manual irrigation scheduling based on a $100 \%$ replenishment of crop water use as determined by weekly manual neutron probe soil water content readings, and it showed the potential to out-yield manual irrigation scheduling. They also found that varying the temperature threshold and recalculating the time threshold accordingly for well-watered crops resulted in different temperature and time threshold combinations that produced the same irrigation regime. This demonstrated that the TTT method was essentially empirical and acted as a feedback irrigation control system in operation.

The studies by Wanjura et al. $(1992,1995)$ and Evett et al. (1996) relied on IRTs mounted in fixed positions in the field and wired to dataloggers, a system that was not compatible with commercial farming practices. Mounting the IRTs on a moving center pivot irrigation system would remove the wires from the field but only would provide data for a short time from each part of the field covered by the moving system. Building on work by Evett et al. (1994) for estimating spatially variable daily evaporation from bare soil, a method (Peters and Evett, 2004a) was developed for scaling one-time-of-day canopy temperature measurements to recreate the diurnal progression of temperature at any given location (fig. 4). This demonstrated that center pivot irrigation could be automated using IRTs mounted on the moving system with only a single diurnal reference temperature measurement in a well-watered part of the field (Peters and Evett, 2004b). Additionally, inexpensive methods for determining pivot lateral position using GPS receivers were developed to improve the spatial accuracy of data from the moving irrigation system (Peters and Evett, 2005). The methods were successfully applied to corn (O'Shaughnessy et al., 2017), cotton (O'Shaughnessy and Evett, 2010b; O'Shaughnessy et al., 2011a), sorghum (O'Shaughnessy et al., 2012a, 2013a), and soybean (O'Shaughnessy et al., 2011a; Peters and Evett, 2008).

Recognizing that IRT wires increased cost, complexity, and maintenance, the USDA-ARS Conservation and Production Research Laboratory (CPRL) at Bushland, Texas, developed a wireless IRT using an XBee radio module and integrated the wireless IRT sensor network into the center pivot control system (O'Shaughnessy and Evett, 2007, 2008, 2009, 2010a; O'Shaughnessy et al., 2009, 2011a, 2012c). The sensors and wireless sensor network were evaluated for accuracy and insensitivity to sensor body heating (O'Shaughnessy et al., 2009, 2011c). Additionally, the USDA-ARS CPRL initiated a cooperative research and development agreement (CRADA) with Dynamax, Inc. (Houston, Tex.) in 2013 that developed a commercial version of a narrow field-of-view, wireless sensor and sensor network with an open sensor network communications protocol (Zigbee) that became commercially available in 2014 (SapIP-IRT, Dynamax, Inc.). Using a calibrated black body in a temperature-controlled environmental chamber, tests done after field deployment showed this system to remain accurate after field deployment (Colaizzi et al., 2018) and thus reusable over multiple years, a result borne out by later experience. The system was demonstrated to be effective and accurate both when mounted in fixed positions in the field and when mounted on a moving center pivot lateral with minimal error due to sensor motion (Colaizzi et al., 2019). Dynamax sells the SapIP-IRT in wireless and cabled (SDI-12) versions nationally and internationally. Independently, Mahan et al. (2010) developed a CRADA with Smartfield, Inc. (Lubbock, Tex.) that resulted in a commercial wireless sensor system with a proprietary interface (Smartcrop Automated Crop Stress Monitoring System). For more discussion on the purposes of CRADAs, see https://en.wikipedia.org/wiki/Cooperative_research_and_ development_agreement.
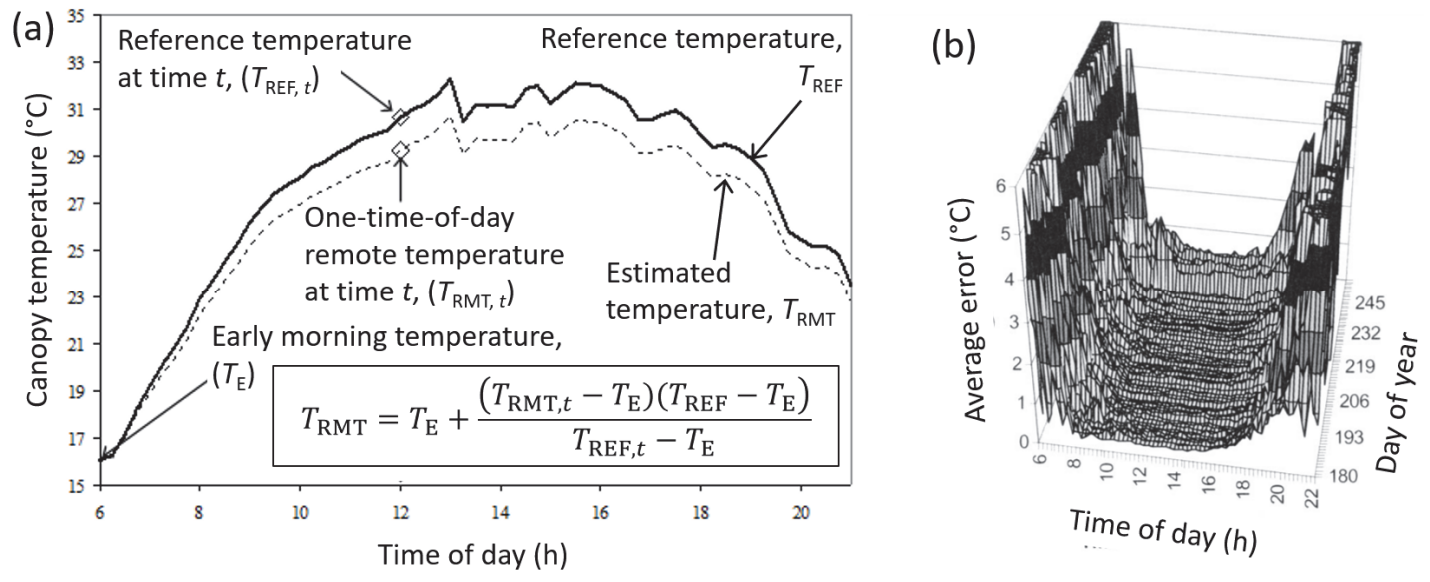

Figure 4. (a) Graph illustrating application of the scaling equation shown to calculate a remote temperature ( $\left.T_{\mathrm{RMT}}\right)$ at any time $t$ from a diurnal reference temperature $\left(T_{\mathrm{REF}}\right)$ curve and a one-time-of-day canopy temperature measurement at the remote location $\left(T_{\mathrm{RMT}, t}\right)$ and $(\mathrm{b})$ illustration of the average error occurring when the scaling method was applied throughout an irrigations season. Error $>1^{\circ} \mathrm{C}$ was mostly confined to $2 \mathrm{~h}$ after sunrise and to $2 \mathrm{~h}$ before sunset. Adapted from Peters and Evett (2004a). 


\section{SOIL WATER SENSING}

Throughout the previously discussed investigations into plant temperature sensing and the development and use of algorithms for irrigation scheduling based on canopy temperature, the default soil water sensing method and the standard for scientific irrigation scheduling based on soil water was the neutron probe (NP) (Gardner and Kirkham, 1952; Hignett and Evett, 2002; Evett, 2008). Investigations into the relationships between SDD, CWSI, and soil water depletion relied on NP data that allowed determination of soil profile water content from the surface to depths well below the root zone. In almost all irrigation scheduling studies described herein, the NP was used as the control scheduling method. Despite the introduction of time domain reflectometry (TDR), time domain transmission (TDT), capacitance, and other electromagnetic (EM) methods of soil water sensing, introduced in the 1970s and later, the EM methods have been slow to replace the NP in scientific studies due to issues of inaccuracy, lack of representivity (can they accurately and reliably represent the profile soil water content), and practicability (number of sensors, expense, complexity, lack of portability) in deployments that adequately cover the soil profile to depths well below the root zone (Evett et al., 2009, 2010, 2012; Mazahrih et al., 2008).

Despite the wide commercial availability of time domain and capacitance-based soil water sensors, their use in irrigation management is still problematic. Problems include incompatibility of equipment in fields with farming operations (particularly cables and masts); complexity, cost, inaccuracy, and lack of representivity as discussed in the previous paragraph; costs to purchase, install, maintain, and process data from systems; and lack of decision support systems that convert data into irrigation decisions. Evett et al. (2006, 2009, 2010, 2012) evaluated a subset of EM sensors for use in irrigation management and found only one that was reasonably accurate, a sensor based on time domain transmission (TDT) principles. Many sensors are sensitive to soil bulk electrical conductivity changes related to soil temperature dynamics, clay content and type, and addition of fertilizers or salts left behind by evaporating irrigation water. Although TDR- and TDT-based EM sensors are less sensitive to interference from soil bulk EC changes and are consistently the most accurate of soil water sensors, these systems remained complex and expensive until recently.

Evett developed a solar-powered TDR system that integrated a TDR instrument (Tektronix 1502 series), a laptop computer, three-electrode TDR probes, a coaxial multiplexer (Evett, 1998), and supervisory control and data acquisition (SCADA) software that controlled the TDR instrument and multiplexer, acquired data from the TDR probes, and processed it to deliver water content data (Evett, 2000a, $2000 \mathrm{~b}$ ). The system was sold to researchers and environmental managers nationally and internationally in the early 1990s (Vadose Zone Equipment Co., Amarillo, Tex.) before being transferred through a CRADA in 1995 and being sold as the Vadose TDR system by Dynamax, Inc. Although the system was used in an automated irrigation scheduling system (Lascano et al., 1996; Lascano, 2000), it was too complex and costly for use on farms. Other conventional TDR systems were similarly too complex and costly for on-farm use.
However, Anderson (2001) developed a sensor based on TDT principles that included all the sensor electronics needed to measure travel time in miniaturized form in the sensor head, greatly reducing the cost and eliminating the need for a TDR instrument, a coaxial multiplexer, and the associated SCADA controller and cables. The TDT sensor used closed-loop electrodes that could not be inserted into the soil, so it was little used for deep installations despite being shown to be accurate and superior to other EM sensors tested (Blonquist et al., 2005; Chávez and Evett, 2012).

Recognizing the need for an automated, standalone sensing system to replace the NP, the USDA-ARS CPRL began development of a down-hole sensing system based on a multiplicity of TDR electrodes embedded into the outside of a plastic tube to sense water content in $20 \mathrm{~cm}$ increments (Casanova et al., 2011, 2012a, 2012b, 2012c). Initial trials used a TDR instrument connected through a multiplexer via coaxial cables to each set of electrodes (waveguides), but the team recognized the need to embed the TDR electronics in the plastic tube in miniaturized, low cost, and low power form and therefore developed a CRADA with Acclima, Inc. (Meridian, Ida.) to develop and test the necessary electronics, leading to a joint patent on the system with Acclima (Evett et al., 2015). In two more CRADAs and SBIR (Small Business Innovative Research, https://www.sbir.gov/) grants, the Acclima and USDA-ARS CPRL team developed improved technologies including individual TDR sensors (e.g., models TDR-315x, TDR-310X) that featured three pointed electrodes that could be inserted into the soil. Evaluation showed that the new sensors could accurately determine soil apparent permittivity, temperature, water content, and bulk electrical conductivity (Schwartz et al., 2016; Evett et al., 2019). Equipment and methods were devised to install sensors to depths $>2 \mathrm{~m}$.

Although the new TDR sensors featured low power consumption, relatively low cost, and an industry-standard SDI12 communications protocol for easy reading by most dataloggers, they still required cables, which made their use in agricultural fields difficult. A USDA-ARS team at Beltsville, Maryland, recognized this impediment and the need for wireless data transmission from the sensor to the edge of field and from the edge of field to the internet cloud, where data could be accessed from anywhere. This team developed a wireless node and gateway system based on the Arduino open-source hardware/software platform. The solar-powered node was connected to sensors in the field using the SDI-12 protocol and sent data using a LoRa (https://lora-alliance.org/) standard radio to the gateway. The gateway synchronized with several nodes, received their data, and then uploaded the data over the cellular telephone network to the internet for storage and access (Evett et al., 2018). The Beltsville USDA-ARS team then collaborated with the Bushland USDA-ARS team and Acclima to develop a commercial version, which has been tested in several U.S. states, Jordan, and Uzbekistan with both the Acclima SDI-12 soil water sensors and the Dynamax SDI-12 IRTs (fig. 5). Both the TDR soil water sensors and the node and gateway system are sold nationally and internationally by Acclima, Inc. 


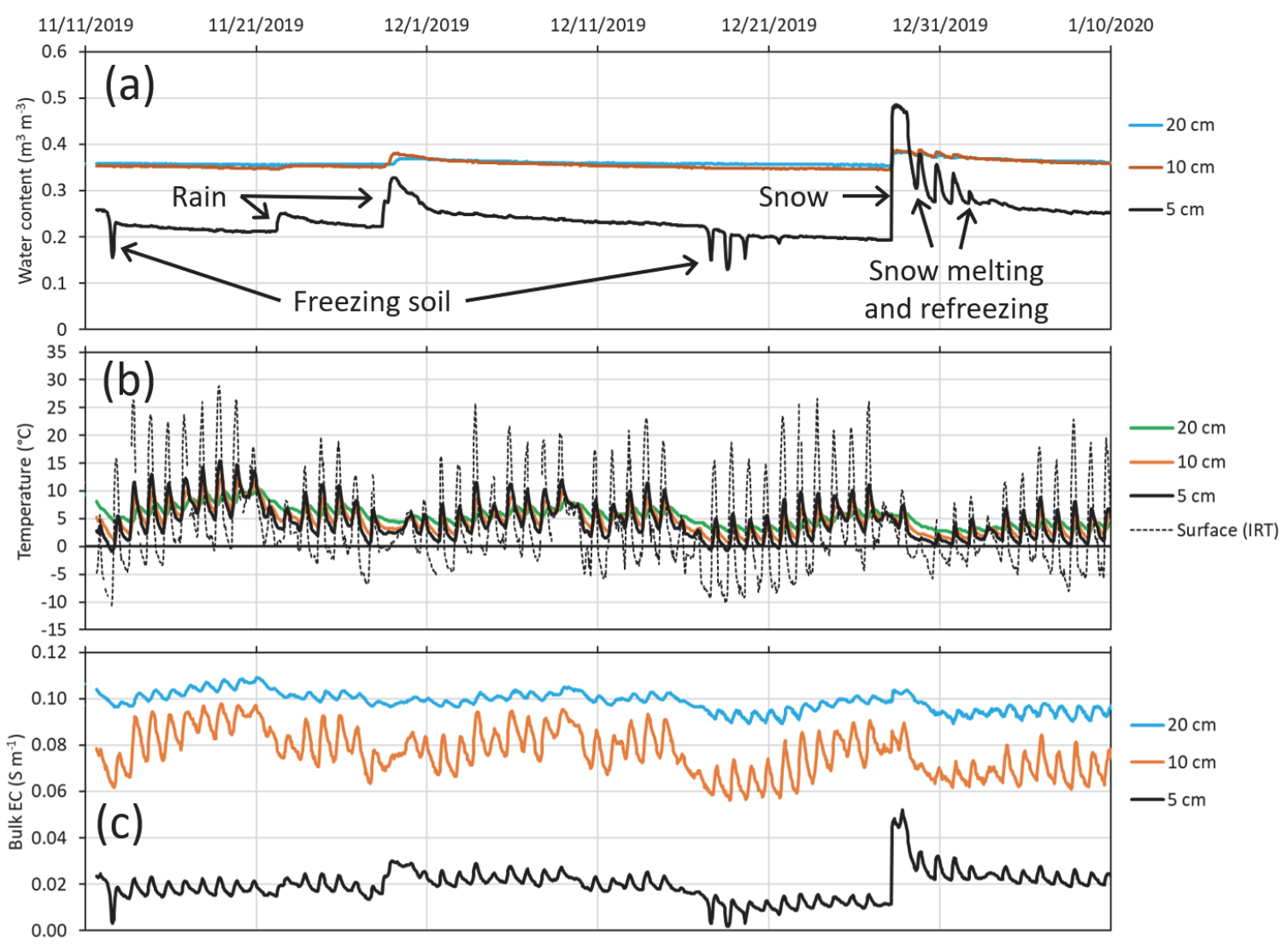

Figure 5. (a) Soil water content, (b) temperature, and (c) bulk electric conductivity (EC) data from TDR-315H and SapIP-IRT sensors installed at Bushland, Texas. Data were transferred wirelessly to the internet using the ARS node and gateway system developed with Acclima, Inc. The data indicate the effects of soil freezing that reduces liquid water content, precipitation that increases soil water content, and daily snow melting that increases water content followed by soil water drainage after snow refreezes for four days after a heavy snowfall.

\section{CONVERGENCE OF SYSTEMS FOR AUTOMATED \\ CENTER Pivot IRRIGATION SCHEdULing}

Although automated irrigation management of center pivot systems based on canopy temperature indices had been shown to be feasible as early as 1995 with IRTs mounted in the field (Wanjura et al., 1995) and by 2002 using IRTs mounted on a center pivot lateral (Peters and Evett, 2004a, 2004b), development of a commercially feasible ISSCADA system depended on the advances in sensor technology and wireless sensor networks described previously as well as advances in water stress indices involving both plant and soil sensors. Through three successive CRADAs, the USDAARS CPRL worked with Valmont Industries, Inc. (Valley, Neb.) to integrate the ISSCADA system with Valley center pivot equipment and control systems, resulting in Valmont licensing the ISSCADA patent in 2018. Goals of the CRADAs for both Valmont and the USDA-ARS were to develop the system into a commercial product and field test the beta version for multiple years on center pivot VRI systems in semi-arid, sub-humid, and humid climates and on different soils with different crops (Evett et al., 2019; O'Shaughnessy et al., 2018a; Stone et al., 2019; Vories et al., 2017, 2019).

Initial research at Bushland used the TTT index successfully (Evett et al., 1996, 2000; Peters and Evett, 2004b, 2006, 2008), but use of the TTT index in other, more humid, climates revealed that it did not provide clear irrigation signals when humidity was high enough to limit crop transpiration.
The CWSI was reported to have different non-stressed baselines depending on climate (Payero and Irmak, 2006; Abritta and Garcia, 2012), but using the theoretical CWSI of Jackson et al. (1988) should somewhat mitigate this by avoiding the use of empirical baselines. Specifically, the baseline using the theoretical CWSI explicitly accounts for the available energy and aerodynamic components of the soil-plantatmosphere energy balance. Because of this, the theoretical CWSI has been shown to be more responsive to climatic variability (e.g., humidity) compared to a CWSI using empirical baselines. The USDA-ARS CPRL mitigated other problems with using canopy temperature based irrigation indices, such as scattered clouds, sun angle, and shaded canopies, by integrating data from $2 \mathrm{~h}$ after sunrise until $2 \mathrm{~h}$ before sunset on a 1 min basis and by using two IRTs mounted to view the canopy from opposite sides in every irrigation zone and at a $45^{\circ}$ depression from horizontal to minimize viewing of the soil background (Peters and Evett, 2004a, 2004b). Research has shown that using the empirical CWSI (eCWSI) resulted in the same relationships between eCWSI and leaf water potential, between eCWSI and water use, and between eCWSI and yield (O'Shaughnessy and Evett, 2009; O'Shaughnessy et al., 2011a) as earlier studies. The studies also demonstrated that center pivot mounted IRTs and the scaling algorithm of Peters and Evett (2004a) collectively could be used to map CWSI in the field for cotton and soybean. With the 
advent of commercially available VRI center pivot equipment, O'Shaughnessy et al. (2011b, 2013b) demonstrated the utility of a VRI system in the high-wind environment of Bushland, Texas. They followed that work with demonstration of the use of the theoretical CWSI integrated over daylight hours (iCWSI) to map corn, sorghum, and cotton water stress and guide irrigation using a SCADA system controlling a VRI center pivot using an embedded computer installed at the pivot point, the ISSCADA system (O'Shaughnessy et al., 2012b, 2015, 2017).

Beginning in 2015, the software embodying the ISSCADA system was converted to a client-server architecture with a geographic information system (GIS) based graphical user interface (GUI) and was named ARSPivot (Andrade et al., 2015, 2016, 2017). ARSPivot's GUI allows its users to inspect recommended site-specific prescription maps generated by the ISSCADA system and to monitor their application by VRI center pivots. The GIS framework allowed addition of important features including kriging and mapping of three-dimensional data (e.g., topographic and yield data) and display of important third-party data such as satellite imagery and USDA-NRCS soil maps (Andrade et al., 2020a, 2020b). Beginning in 2015, a USDA-ARS multilocation research project combined the efforts of USDAARS laboratories at Bushland, Texas; Florence, South Carolina; Portageville, Missouri; and Stoneville, Mississippi, for a multi-year beta test of the ISSCADA system in humid and sub-humid climates, on a wide range of soils, and with different center pivot irrigation application methods. Despite the adoption of the theoretical and integrated CWSI, results from beta test partners in Mississippi, Missouri, and South Carolina indicated that the integrated CWSI could be misleading in high-humidity situations, leading to the development of an application programming interface (API) for soil water sensing in ARSPivot. The API was used to bring wireless data from a soil water sensing system based on the Acclima TDR sensors into the ISSCADA algorithm (Andrade et al., 2020a, 2020b). Using a multi-level decision algorithm to apply varying degrees of water depending on relative crop water stress and soil water status, Stone et al. (2019) successfully used this system for corn irrigation management in South Carolina, while O'Shaughnessy et al. (2020) successfully used the system to manage sorghum irrigation at Bushland, avoiding over-irrigation that can depress yields.

\section{CONTINUOUS IMPROVEMENT}

The ISSCADA system for VRI center pivot irrigation management is functional and produces yields greater than county-wide mean yields where it has been so compared, while producing yield and crop water productivity on a par with or better than those produced with scheduling based on weekly NP readings, the acknowledged most accurate scientific irrigation scheduling method (O'Shaughnessy et al., $2012 \mathrm{~b}, 2015,2017)$. However, the ISSCADA system is continuously being improved. Recent work has focused on invention of new, more capable sensors able to detect abiotic and biotic stresses as well as canopy cover factors and soil background influences using a combination of infrared and multi-band sensing (O'Shaughnessy et al., 2016b) and a combination of infrared and computer vision sensing
(O'Shaughnessy et al., 2018b). Data from both sensors provide information for decision support algorithms related to the initiation of automatic irrigation scheduling as a function of crop canopy cover and water stress. The sensors also support the qualification of temperature data used in automatic irrigation scheduling algorithms by screening out data that are compromised by soil background radiation, as well as the detection of diseased crops, with one purpose being withholding irrigation when yield potential is compromised.

As noted previously, the relationships between soil water indices (e.g., root zone soil water deficit, root zone profile water content, etc.) and canopy temperature-based indices have been shown to be inconsistent, particularly on a daily basis and in midseason. Recent research indicates that the relationships are stronger if soil water data are assimilated into a root water uptake and transpiration model (Shi et al., 2015; Wu et al., 2017), but the added complexity renders this approach difficult for generalization into an irrigation management approach. So far, there is no general solution to the problem of relating a few accurate soil water data collected continuously at specific field locations to spatially complete but intermittent canopy temperature-based plant water stress indices.

Colaizzi et al. (2012a, 2012b, 2014, 2016, 2017) made important improvements to the two-source energy balance (TSEB) model, demonstrating the feasibility of using canopy temperature data from IRTs mounted on a center pivot lateral with the TSEB model to determine spatially variable crop ET. Colaizzi et al. (2017) suggested that use of the multi-band and computer vision sensors developed by O'Shaughnessy et al. (2016b, 2018b) could improve ET accuracy by detecting canopy cover factor and improving partitioning of detected temperature to soil and canopy cover components. Recently, Andrade et al. (2018) applied machine learning algorithms to forecast canopy temperature and spatial patterns of iCWSI based on previous spatial canopy temperature data and subsequent weather. Additionally, ARSPivot can import thermometric maps from aerial platforms, so work is ongoing to correlate canopy temperature maps from the IRTs on the moving irrigation system with the aerial data.

\section{Conclusions}

This article has reviewed the theoretical and practical background of advances in plant and soil sensing that, combined with VRI equipment, allowed the development of a commercially practical irrigation scheduling supervisory control and data acquisition (ISSCADA) system and its subsystem components. The review reveals important lessons.

First, long-term research on several fronts, long-range research planning, assembling and re-arranging of research and development teams, and a long-range and flexible vision of what would constitute a practical system were required to achieve this end. It is not a coincidence that this work was done within the USDA-ARS, which has long-term funding for stable staffing. The work occurred over at least five project plans, each five years in duration, that were part of the USDA-ARS National Program for Water Availability and 
Watershed Management (NP201 in the past and NP211 presently).

Second, both long-term goals (development of an automatic irrigation scheduling decision support system) and short-term objectives (e.g., research publications, invention, and commercialization of sensors) were necessary to keep the work moving forward. Successful proposals for grants and CRADAs that kept the long-term effort going were predicated on results from shorter-term research that answered questions and opened up new lines of investigation and opportunities for commercialization.

Third, work was split among multiple locations and partners, including international partners for both the soil water sensing and the plant stress sensing work. This allowed research in a wide range of environmental conditions. Support for multi-location research efforts within the USDA-ARS was essential for success, as was support for cooperative research with international and commercial partners.

Fourth, several grants were essential to funding the extra materiel and staff needed for key parts of the project. Grants included those from BARD (Binational Agricultural Research and Development fund), FAO/IAEA (UN Food and Agriculture Organization and the International Atomic Energy Agency), USDA NRI (National Research Initiative), USDA NIFA (National Institute for Food and Agriculture), and USDA SBIR (Small Business Innovative Research fund). The grants supported efforts by both the USDA-ARS and its partners, including university, international, and commercial partners.

Fifth, mechanisms for transferring technology to the commercial sector were key to making the developed technology available to the public through the commercial partners. Within the federal government, those mechanisms are the cooperative research and development agreement (CRADA) and the material transfer research agreement (MTRA); universities have similar mechanisms.

Sixth, support for patenting of key inventions was important to provide confidence to potential CRADA partners that their intellectual and monetary contributions would not be compromised in the marketplace.

Of course, it is possible to make progress without longterm support of a research team, but the example given in this article argues that progress is more likely to meet overall goals if a long-term vision and effort are made possible.

\section{ACKNOWLEDGEMENTS}

This material is based on work that was supported by the USDA National Institute of Food and Agriculture under Award No. 2016-67021-24420, by BARD TDA/TIE under Award No. TIE04-01, and by IAEA under Award Nos. 18210/R2, 58-3090-6-003-F, UZB/5/002, and ZIM5011. The work reported in this article was also accomplished as part of cooperative research and development agreements (CRADAs) between the USDA-ARS and Valmont Industries, Inc., Valley, Nebraska (Agreement Nos. 58-3090-6001, 58-3K95-0-1455-M, and 58-3K95-3-1623), Acclima, Inc., Meridian, Idaho (Agreement Nos. 58-3090-5-011, 588042-8-020, 58-3K95-0-1447-M, and 58-3090-9-001), and Dynamax, Inc., Houston, Texas (Agreement Nos. 58-3K955-405 and 58-3K95-3-1613). We also acknowledge support from the USDA-ARS Ogallala Aquifer Program, a consortium between the USDA-ARS, Kansas State University, Texas A\&M AgriLife Research, Texas A\&M AgriLife Extension Service, Texas Tech University, and West Texas A\&M University.

\section{REFERENCES}

Abritta, M. A., \& Garcia, A. (2012). Crop water stress index and non-stressed baseline of corn grown in the state of Wyoming, U.S. ASABE Paper No. 121337804. St. Joseph, MI: ASABE. https://doi.org/10.13031/2013.42166

Anderson, S. K. (2001). Absolute-reading soil moisture and conductivity sensor. U.S. Patent No. 6,657,443 B2.

Andrade, M. A., Evett, S. R., \& O'Shaughnessy, S. A. (2018). Machine learning algorithms applied to the forecasting of crop water stress indicators. Proc. Irrig. Show and Educ. Conf. Fairfax, VA: Irrigation Association. Retrieved from http://www.irrigation.org/IA/FileUploads/IA/Resources/Technic alPapers/2018/Machine_Learning_Algorithms_Forecasting_AN DRADE.pdf

Andrade, M. A., O’Shaughnessy, S. A., \& Evett, S. R. (2015). Advances in irrigation management tools: The development of ARSmartPivot. Proc. ASABE / IA Irrigation Symp.: Emerging Technologies for Sustainable Irrigation . St. Joseph, MI: ASABE. https://doi.org/10.13031/irrig.20152170793

Andrade, M. A., O'Shaughnessy, S. A., \& Evett, S. R. (2016). A GIS-based decision support tool for center pivot irrigation systems. ASABE Paper No. 162461449. St. Joseph, MI: ASABE. https://doi.org/10.13031/aim.20162461449

Andrade, M. A., O'Shaughnessy, S. A., \& Evett, S. R. (2017). ARSPivot, a sensor-based decision support tool for the integrated irrigation management of VRI center pivot systems. Proc. 28th Annual Central Plains Irrigation Conf. (pp. 5-14). Colby, KS: Central Plains Irrigation Association. Retrieved from https://www.ksre.k-state.edu/irrigate/oow/p17/Andrade17.pdf

Andrade, M. A., O'Shaughnessy, S. A., \& Evett, S. R. (2020a). ARSPivot, a sensor-based decision support software for variable-rate irrigation center pivot systems. Part A: Development. Trans. ASABE, 63(5), https://doi.org/10.13031/trans.13907, in press.

Andrade, M. A., O’Shaughnessy, S. A., \& Evett, S. R. (2020b). ARSPivot, a sensor-based decision support software for variable-rate irrigation center pivot systems. Part B: Application. Trans. ASABE, 63(5), https://doi.org/10.13031/trans.13908, in press.

Barnes, E. M., Clarke, T. R., Richards, S. E., Colaizzi, P. D., Haberland, J., Kostrzewski, M., ... Thompson, T. (2000). Coincident detection of crop water stress, nitrogen status. and canopy density using ground-based multispectral data. In P. C. Robert, E. H. Rust, \& W. E. Larson (Eds.), Proc. 5th Intl. Conf. on Precision Agriculture. Madison, WI: ASA, CSSA, SSSA.

Blonquist Jr., J. M., Jones, S. B., \& Robinson, D. A. (2005). A time domain transmission sensor with TDR performance characteristics. J. Hydrol., 314(1), 235-245. https://doi.org/10.1016/j.jhydrol.2005.04.005

Burke, J. J., Hatfield, J. L., \& Wanjura, D. F. (1990). A thermal stress index for cotton. Agron. J., 82(3), 526-530. https://doi.org/10.2134/agronj1990.00021962008200030018x

Burke, J. J., Mahan, J. R., \& Hatfield, J. L. (1988). Crop-specific thermal kinetic windows in relation to wheat and cotton biomass production. Agron. J., 80(4), 553-556. https://doi.org/10.2134/agronj1988.00021962008000040001x Casanova, J. J., Evett, S. R., \& Schwartz, R. C. (2011). Design and testing of access-tube TDR soil water sensor. ASABE Paper No. 
1110994. St. Joseph, MI: ASABE. https://doi.org/10.13031/2013.37387

Casanova, J. J., Evett, S. R., \& Schwartz, R. C. (2012a). Design of access-tube TDR sensor for soil water content: Theory. IEEE Sensors J., 12(6), 1979-1986. https://doi.org/10.1109/JSEN.2011.2181354

Casanova, J. J., Evett, S. R., \& Schwartz, R. C. (2012b). Design of access-tube TDR sensor for soil water content: Testing. IEEE Sensors J., 12(6), 2064-2070. https://doi.org/10.1109/JSEN.2012.2184282

Casanova, J. J., Evett, S. R., \& Schwartz, R. C. (2012c). Design and field tests of an access-tube soil water sensor. Appl. Eng. Agric., 28(4), 603-610. https://doi.org/10.13031/2013.42075

Chávez, J. L., \& Evett, S. R. (2012). Using soil water sensors to improve irrigation management. Proc. 24th Annual Central Plains Irrigation Conf. (pp. 187-202). Colby, KS: Central Plains Irrigation Association. Retrieved from https://www.ksre.kstate.edu/irrigate/oow/p12/Chavez12.pdf

Clark, R. N., \& Hiler, E. A. (1973). Plant measurements as indicators of crop water deficit. Crop Sci., 13(4), 466-469. https://doi.org/10.2135/cropsci1973.0011183X001300040022x

Colaizzi, P. D., Agam, N., Tolk, J. A., Evett, S. R., Howell Sr, T. A., O'Shaughnessy, S. A., ... Anderson, M. C. (2016). Advances in a two-source energy balance model: Partitioning of evaporation and transpiration for cotton. Trans. ASABE, 59(1), 181-197. https://doi.org/10.13031/trans.59.11215

Colaizzi, P. D., Agam, N., Tolk, J. A., Evett, S. R., Howell, T. A., Gowda, P. H., ... Anderson, M. C. (2014). Two-source energy balance model to calculate E, T, and ET: Comparison of Priestley-Taylor and Penman-Monteith formulations and two time scaling methods. Trans. ASABE, 57(2), 479-498. https://doi.org/10.13031/trans.57.10423

Colaizzi, P. D., Barnes, E. M., Clarke, T. R., Choi, C. Y., \& Waller, P. M. (2003a). Estimating soil moisture under low-frequency surface irrigation using crop water stress index. J. Irrig. Drain. Eng., 129(1), 27-35. https://doi.org/10.1061/(ASCE)07339437(2003)129:1(27)

Colaizzi, P. D., Barnes, E. M., Clarke, T. R., Choi, C. Y., Waller, P. M., Haberland, J., \& Kostrzewski, M. (2003b). Water stress detection under high-frequency sprinkler irrigation with water deficit index. J. Irrig. Drain. Eng., 129(1), 36-43. https://doi.org/10.1061/(ASCE)0733-9437(2003)129:1(36)

Colaizzi, P. D., Evett, S. R., Howell, T. A., Gowda, P. H., O'Shaughnessy, S. A., Tolk, J. A., ... Anderson, M. C. (2012a). Two-source energy balance model: Refinements and lysimeter tests in the Southern High Plains. Trans. ASABE, 55(2), 551562. https://doi.org/10.13031/2013.41385

Colaizzi, P. D., Kustas, W. P., Anderson, M. C., Agam, N., Tolk, J. A., Evett, S. R., ... O'Shaughnessy, S. A. (2012b). Two-source energy balance model estimates of evapotranspiration using component and composite surface temperatures. Adv. Water Resour., 50, 134-151. https://doi.org/10.1016/j.advwatres.2012.06.004

Colaizzi, P. D., O’Shaughnessy, S. A., \& Evett, S. R. (2018). Calibration and tests of commercial wireless infrared thermometers. Appl. Eng. Agric., 34(4), 647-658. https://doi.org/10.13031/aea.12577

Colaizzi, P. D., O'Shaughnessy, S. A., Evett, S. R., \& Andrade, M. A. (2019). Comparison of stationary and moving infrared thermometer measurements aboard a center pivot. Appl. Eng. Agric., 35(6), 853-866. https://doi.org/10.13031/aea.13443

Colaizzi, P. D., O’Shaughnessy, S. A., Evett, S. R., \& Mounce, R. B. (2017). Crop evapotranspiration calculation using infrared thermometers aboard center pivots. Agric. Water Mgmt., 187, 173-189. https://doi.org/10.1016/j.agwat.2017.03.016
DeJonge, K. C., Taghvaeian, S., Trout, T. J., \& Comas, L. H. (2015). Comparison of canopy temperature-based water stress indices for maize. Agric. Water Mgmt., 156, 51-62. https://doi.org/10.1016/j.agwat.2015.03.023

Ehrler, W. L. (1973). Cotton leaf temperatures as related to soil water depletion and meteorological factors. Agron. J., 65(3), 404-409. https://doi.org/10.2134/agronj1973.00021962006500030016x

Ehrler, W. L., Idso, S. B., Jackson, R. D., \& Reginato, R. J. (1978a). Diurnal changes in plant water potential and canopy temperature of wheat as affected by drought. Agron. J., 70(6), 999-1004. https://doi.org/10.2134/agronj1978.00021962007000060027x

Ehrler, W. L., Idso, S. B., Jackson, R. D., \& Reginato, R. J. (1978b). Wheat canopy temperature: Relation to plant water potential. Agron. J., 70(2), 251-256. https://doi.org/10.2134/agronj1978.00021962007000020010x

Evett, S. R. (1998). Coaxial multiplexer for time domain reflectometry measurement of soilwater content and bulk electrical conductivity. Trans. ASAE, 41(2), 361-369. https://doi.org/10.13031/2013.17186

Evett, S. R. (2000a). The TACQ computer program for automatic time domain reflectometry measurements: I. Design and operating characteristics. Trans. ASAE, 43(6), 1939-1946. https://doi.org/10.13031/2013.3099

Evett, S. R. (2000b). The TACQ computer program for automatic time domain reflectometry measurements: II. Waveform interpretation methods. Trans. ASAE, 43(6), 1947-1956. https://doi.org/10.13031/2013.3100

Evett, S. R. (2008). Neutron moisture meters. In S. R. Evett, L. K. Heng, P. Moutonnet, \& M. L. Nguyen (Eds.), Field estimation of soil water content: A practical guide to methods, instrumentation, and sensor technology (pp. 39-54). IAEA-TCS30. Vienna, Austria: International Atomic Energy Agency. Retrieved from http://wwwpub.iaea.org/mtcd/publications/PubDetails.asp?pubId=7801

Evett, S. R., Anderson, S. K., Casanova, J. J., \& Schwartz, R. C. (2015). Soil water and conductivity sensing system. U.S. Patent No. 8,947,102 B1.

Evett, S. R., Howell, T. A., Schneider, A. D., Upchurch, D. R., \& Wanjura, D. F. (1996). Canopy temperature based automatic irrigation control. In C. R. Camp, E. J. Sadler, \& R. E. Yoder (Ed.), Proc. Intl. Conf. Evapotranspiration and Irrigation Scheduling (pp. 207-213). St. Joseph, MI: ASABE. Retrieved from http://handle.nal.usda.gov/10113/1662

Evett, S. R., Howell, T. A., Schneider, A. D., Upchurch, D. R., \& Wanjura, D. F. (2000). Automatic drip irrigation of corn and soybean. In R. G. Evans, B. L. Benham, \& T. P. Trooien (Ed.), Proc. 4th Decennial National Irrigation Symp. (pp. 401-408). St. Joseph, MI: ASABE.

Evett, S. R., Matthias, A. D., \& Warrick, A. W. (1994). Energy balance model of spatially variable evaporation from bare soil. SSSA J., 58(6), 1604-1611. https://doi.org/10.2136/sssaj 1994.03615995005800060003x

Evett, S. R., O'Shaughnessy, S. A., \& Peters, R. T. (2014a). Irrigation scheduling and supervisory control data acquisition system for moving and static irrigation systems. U.S. Patent No. 8,924,031 B1.

Evett, S. R., O'Shaughnessy, S. A., Andrade, M. A., Kustas, W. P., Anderson, M. C., Schomberg, H. S., \& Thompson, A. (2020). Precision agriculture and irrigation: Current U.S. perspectives. Trans. ASABE, 63(1), 57-67.

https://doi.org/10.13031/trans.13355

Evett, S. R., O'Shaughnessy, S. A., Colaizzi, P. D., \& Schwartz, R. C. (2014b). Soil water sensing: Implications of sensor capabilities for variable-rate irrigation management. Proc. Irrig. Show and Educ. Conf. Fairfax, VA: Irrigation Association. 
Retrieved from

http://www.irrigation.org/IA/FileUploads/IA/Resources/Technic alPapers/2014/SoilWaterSensingImplicationsOfSensorCapabiliti esForVariableRateIrrigationManagement.pdf

Evett, S. R., O’Shaughnessy, S. A., Colaizzi, P. D., \& Schwartz, R. C. (2016). Relating soil-available water fraction to water stress indices. Proc. Irrig. Show and Educ. Conf. Fairfax, VA: Irrigation Association. Retrieved from

http://www.irrigation.org/IA/FileUploads/IA/Resources/Technic alPapers/2016/RelatingSoilAvailableWaterFractiontoWaterStres sIndices.pdf

Evett, S. R., O’Shaughnessy, S. A., Colaizzi, P. D., Schwartz, R. C., \& Howell, T. A. (2013). Irrigated agriculture with limited water supply: Tools for understanding and managing irrigation and crop water use efficiencies. Presentation No. 96-1. Proc. ASA, CSSA, SSSA Intl. Annual Meeting. Madison, WI: ASA, CSSA, SSSA. Retrieved from

https://dl.sciencesocieties.org/publications/meetings/download/p df/2013am/78789

Evett, S. R., Schomberg, H. S., Thompson, A., Schwartz, R. C., O'Shaughnessy, S. A., \& Andrade, M. A. (2018). Water in the cloud: A new system for field water monitoring with cloud data access. Proc. Irrig. Show and Educ. Conf. Fairfax, VA:

Irrigation Association. Retrieved from http://www.irrigation.org/IA/FileUploads/IA/Resources/Technic alPapers/2018/Water_In_The_Cloud_EVETT.pdf

Evett, S. R., Schwartz, R. C., Casanova, J. J., \& Heng, L. K. (2012). Soil water sensing for water balance, ET, and WUE. Agric. Water Mgmt., 104, 1-9. https://doi.org/10.1016/j.agwat.2011.12.002

Evett, S. R., Schwartz, R. C., Lascano, R. J., \& Pelletier, M. G. (2010). In-soil and down-hole soil water sensors: Characteristics for irrigation management. ASABE Paper No. IRR108346. St. Joseph, MI: ASABE. https://doi.org/10.13031/2013.35844

Evett, S. R., Schwartz, R. C., Tolk, J. A., \& Howell, T. A. (2009). Soil profile water content determination: Spatiotemporal variability of electromagnetic and neutron probe sensors in access tubes. Vadose Zone J., 8(4), 926-941. https://doi.org/10.2136/vzj2008.0146

Evett, S. R., Stone, K. C., Schwartz, R. C., O'Shaughnessy, S. A., Colaizzi, P. D., Anderson, S. K., \& Anderson, D. J. (2019). Resolving discrepancies between laboratory-determined field capacity values and field water content observations: Implications for irrigation management. Irrig. Sci., 37(6), 751759. https://doi.org/10.1007/s00271-019-00644-4

Evett, S. R., Tolk, J. A., \& Howell, T. A. (2006). Soil profile water content determination: Sensor accuracy, axial response, calibration, temperature dependence, and precision. Vadose Zone J., 5(3), 894-907. https://doi.org/10.2136/vzj2005.0149

Fuchs, M., \& Tanner, C. B. (1966). Infrared thermometry of vegetation. Agron. J., 58(6), 597-601. https://doi.org/10.2134/agronj1966.00021962005800060014x

Gardner, B. R., Blad, B. L., Garrity, D. P., \& Watts, D. G. (1981b). Relationships between crop temperature, grain yield, evapotranspiration, and phenological development in two hybrids of moisture stressed sorghum. Irrig. Sci., 2(4), 213-224. https://doi.org/10.1007/BF00258375

Gardner, B. R., Blad, B. L., Maurer, R. E., \& Watts, D. G. (1981a) Relationship between crop temperature and the physiological and phenological development of differentially irrigated corn. Agron. J., 73(4), 743-747.

https://doi.org/10.2134/agronj1981.00021962007300040042x

Gardner, B. R., Nielsen, D. C., \& Shock, C. C. (1992a). Infrared thermometry and the crop water stress index: I. History, theory, and baselines. J. Prod. Agric., 5(4), 462-466.

https://doi.org/10.2134/jpa1992.0462
Gardner, B. R., Nielsen, D. C., \& Shock, C. C. (1992b). Infrared thermometry and the crop water stress index: II. Sampling procedures and interpretation. J. Prod. Agric., 5(4), 466-475. https://doi.org/10.2134/jpa1992.0466

Gardner, W., \& Kirkham, D. (1952). Determination of soil moisture by neutron scattering. Soil Sci., 73, 391-401. https://doi.org/10.1097/00010694-195205000-00007

Hignett, C., \& Evett, S. R. (2002). Section 3.1.3.10: Neutron thermalization. In J. H. Dane \& G. C. Topp (Eds.), Methods of soil analysis: Part 4. Physical methods (pp. 501-521). Madison, WI: SSSA.

Howell, T. A., Musick, J. T., \& Tolk, J. A. (1986). Canopy temperature of irrigated winter wheat. Trans. ASAE, 29(6), 1692-1698. https://doi.org/10.13031/2013.30375

Idso, S. B., \& Baker, D. G. (1967). Relative importance of reradiation, convection, and transpiration in heat transfer from plants. Plant Physiol., 42(5), 631-640. https://doi.org/10.1104/pp.42.5.631

Idso, S. B., Jackson, R. D., \& Reginato, R. J. (1977). Remotesensing of crop yields. Science, 196(4285), 19-25. https://doi.org/10.1126/science.196.4285.19

Idso, S. B., Jackson, R. D., Pinter Jr., P. J., Reginato, R. J., \& Hatfield, J. L. (1981a). Normalizing the stress-degree-day parameter for environmental variability. Agric. Meteorol., 24, 45-55. https://doi.org/10.1016/0002-1571(81)90032-7

Idso, S. B., Reginato, R. J., Reicosky, D. C., \& Hatfield, J. L. (1981b). Determining soil-induced plant water potential depressions in alfalfa by means of infrared thermometry. Agron. J., 73(5), 826-830. https://doi.org/10.2134/agronj1981.00021962007300050019x

Jackson, R. D. (1982). Canopy temperature and crop water stress. In D. Hillel (Ed.), Advances in irrigation (Vol. 1, pp. 43-85). New York, NY: Academic Press. https://doi.org/10.1016/B978-0-12024301-3.50009-5

Jackson, R. D., Idso, S. B., Reginato, R. J., \& Pinter Jr., P. J. (1981). Canopy temperature as a crop water stress indicator. Water Resour. Res., 17(4), 1133-1138. https://doi.org/10.1029/WR017i004p01133

Jackson, R. D., Kustas, W. P., \& Choudhury, B. J. (1988). A reexamination of the crop water stress index. Irrig. Sci., 9(4), 309-317. https://doi.org/10.1007/BF00296705

Jackson, R. D., Reginato, R. J., \& Idso, S. B. (1977). Wheat canopy temperature: A practical tool for evaluating water requirements. Water Resour. Res., 13(3), 651-656. https://doi.org/10.1029/WR013i003p00651

Lascano, R. J. (2000). A general system to measure and calculate daily crop water use. Agron. J., 92(5), 821-832. https://doi.org/10.2134/agronj2000.925821x

Lascano, R. J., Baumhardt, R. L., Hicks, S. K., Evett, S. R., \& Heilman, J. L. (1996). Daily measurement and calculation of crop water use. In C. R. Camp, E. J. Sadler, \& R. E. Yoder (Ed.), Proc. Intl. Conf. Evapotranspiration and Irrigation Scheduling (pp. 225-230). St. Joseph, MI: ASABE.

Mahan, J. R., \& Upchurch, D. R. (1988). Maintenance of constant leaf temperature by plants: I. Hypothesis-limited homeothermy. Environ. Exp. Bot., 28(4), 351-357. https://doi.org/10.1016/0098-8472(88)90059-7

Mahan, J. R., Burke, J. J., \& Orzech, K. A. (1987). The thermal kinetic window as an indicator of optimum plant temperature. Plant Physiol., 82, 518-522.

Mahan, J. R., Conaty, W., Neilsen, J., Payton, P., \& Cox, S. B. (2010). Field performance in agricultural settings of a wireless temperature monitoring system based on a low-cost infrared sensor. Comput. Electron. Agric., 71(2), 176-181. https://doi.org/10.1016/j.compag.2010.01.005 
Mazahrih, N. T., Katbeh-Bader, N., Evett, S. R., Ayars, J. E., \& Trout, T. J. (2008). Field calibration accuracy and utility of four down-hole water content sensors. Vadose Zone J., 7(3), 9921000. https://doi.org/10.2136/vzj2008.0001

Nielsen, D. C. (1990). Scheduling irrigations for soybeans with the crop water stress index (CWSI). Field Crops Res., 23(2), 103116. https://doi.org/10.1016/0378-4290(90)90106-L

O'Shaughnessy, S. A., \& Evett, S. R. (2007). IRT wireless interface for automatic irrigation scheduling of a center pivot system. Proc. 28th Annual Intl. Irrig. Show (pp. 176-186). Fairfax, VA: Irrigation Association. Retrieved from

http://www.irrigation.org/IA/FileUploads/IA/Resources/Technic alPapers/2007/WirelessInfraredThermometersForAutomatedIrri gationSchedulingOfACenterPivot.pdf

O'Shaughnessy, S. A., \& Evett, S. R. (2008). Integration of wireless sensor networks into moving irrigation systems for automatic irrigation scheduling. ASABE Paper No. 083452. St. Joseph, MI: ASABE. https://doi.org/10.13031/2013.24796

O'Shaughnessy, S. A., \& Evett, S. R. (2009). Using radiation thermometry to assess spatial variation of water-stressed cotton. Proc. Irrig. Assoc. Tech. Conf. Fairfax, VA: Irrigaton Association. Retrieved from http://www.irrigation.org/IA/FileUploads/IA/Resources/Technic alPapers/2009/UsingInfraredThermographyToDetermineCropW aterStressInCotton.pdf

O'Shaughnessy, S. A., \& Evett, S. R. (2010a). Developing wireless sensor networks for monitoring crop canopy temperature using a moving sprinkler system as a platform. Appl. Eng. Agric., 26(2), 331-341. https://doi.org/10.13031/2013.29534

O'Shaughnessy, S. A., \& Evett, S. R. (2010b). Canopy temperature based system effectively schedules and controls center pivot irrigation of cotton. Agric. Water Mgmt., 97(9), 1310-1316. https://doi.org/10.1016/j.agwat.2010.03.012

O'Shaughnessy, S. A., Andrade, M. A., \& Evett, S. R. (2017). Using an integrated crop water stress index for irrigation scheduling of two corn hybrids in a semi-arid region. Irrig. Sci., 35(5), 451-467. https://doi.org/10.1007/s00271-017-0552-x

O’Shaughnessy, S. A., Andrade, M. A., Stone, K. C., Vories, E. D., Sui, R., \& Evett, S. R. (2018a). Adapting a VRI irrigation scheduling system for different climates. Proc. Irrig. Show and Educ. Conf. Fairfax, VA: Irrigation Association. Retrieved from http://www.irrigation.org/IA/FileUploads/IA/Resources/Technic alPapers/2018/Adapting_Site-

Specific_Irrigation_OSHAUGHNESSY.pdf, https://www.irrigation.org/IA/Resources/Technical-PaperLibrary.aspx

O’Shaughnessy, S. A., Casanova, J. J., Evett, S. R., \& Colaizzi, P. D. (2018b). Computer vision qualified infrared temperature sensor. U.S. Patent No. 9,866,768 B1.

O’Shaughnessy, S. A., Evett, S. R., \& Colaizzi, P. D. (2015). Dynamic prescription maps for site-specific variable-rate irrigation of cotton. Agric. Water Mgmt., 159, 123-138. https://doi.org/10.1016/j.agwat.2015.06.001

O'Shaughnessy, S. A., Evett, S. R., Andrade, A., Workneh, F., Price, J. A., \& Rush, C. M. (2016a). Site-specific variable-rate irrigation as a means to enhance water use efficiency. Trans. ASABE, 59(1), 239-249. https://doi.org/10.13031/trans.59.11165

O’Shaughnessy, S. A., Evett, S. R., Colaizzi, P. D., \& Howell, T. A. (2011a). Using radiation thermography and thermometry to evaluate crop water stress in soybean and cotton. Agric. Water Mgmt., 98(10), 1523-1535.

https://doi.org/10.1016/j.agwat.2011.05.005

O’Shaughnessy, S. A., Evett, S. R., Colaizzi, P. D., \& Howell, T. A. (2011b). Uniformity testing of a commercial variable-rate center pivot system. Proc. Irrig. Show and Educ. Conf. Fairfax, VA: Irrigation Association. Retrieved from
http://www.irrigation.org/IA/FileUploads/IA/Resources/Technic alPapers/2011/UniformityTestingOfACommercialVariableRate CenterPivotSystem.pdf

O’Shaughnessy, S. A., Evett, S. R., Colaizzi, P. D., \& Howell, T. A. (2012a). Grain sorghum response to irrigation scheduling with the time-temperature threshold method and deficit irrigation levels. Trans. ASABE, 55(2), 451-461. https://doi.org/10.13031/2013.41395

O’Shaughnessy, S. A., Evett, S. R., Colaizzi, P. D., \& Howell, T. A. (2012b). A crop water stress index and time threshold for automatic irrigation scheduling of grain sorghum. Agric. Water Mgmt., 107, 122-132.

https://doi.org/10.1016/j.agwat.2012.01.018

O’Shaughnessy, S. A., Evett, S. R., Colaizzi, P. D., \& Howell, T. A. (2012c). Performance of a wireless sensor network for crop water monitoring and irrigation control. ASABE Paper No. 121338246. St. Joseph, MI: ASABE. https://doi.org/10.13031/2013.41894

O’Shaughnessy, S. A., Evett, S. R., Colaizzi, P. D., \& Howell, T. A. (2013a). Wireless sensor network effectively controls center pivot irrigation of sorghum. Appl. Eng. Agric., 29(6), 853-864. https://doi.org/10.13031/aea.29.9921

O’Shaughnessy, S. A., Evett, S. R., Hebel, M. A., \& Colaizzi, P. D. (2016b). Multi-band photodiode sensor. U.S. Patent No. 9,451,745 B1.

O’Shaughnessy, S. A., Hebel, M. A., \& Evett, S. R. (2009). Developing a wireless infrared thermometer with a narrow field of view. ASABE Paper No. 701P0409e. St. Joseph, MI: ASABE. https://doi.org/10.13031/2013.29034

O’Shaughnessy, S. A., Hebel, M. A., Evett, S. R., \& Colaizzi, P. D. (2011c). Evaluation of a wireless infrared thermometer with a narrow field of view. Comput. Electron. Agric., 76(1), 59-68. https://doi.org/10.1016/j.compag.2010.12.017

O’Shaughnessy, S. A., Kim, M., Andrade, M. A., Colaizzi, P. D., \& Evett, S. R. (2020). Site-specific irrigation of grain sorghum using plant and soil water sensing feedback in the Texas High Plains. Agric. Water Mgmt. (submitted).

O’Shaughnessy, S. A., Urrego, Y. F., Evett, S. R., Colaizzi, P. D., \& Howell, T. A. (2013b). Assessing application uniformity of a variable-rate irrigation system in a windy location. Appl. Eng. Agric., 29(4), 497-510.

https://doi.org/http://dx.doi.org/10.13031/aea.29.9931

Payero, J. O., \& Irmak, S. (2006). Variable upper and lower crop water stress index baselines for corn and soybean. Irrig. Sci., 25(1), 21-32. https://doi.org/10.1007/s00271-006-0031-2

Peters, R. T., \& Evett, S. R. (2004a). Modeling diurnal canopy temperature dynamics using one-time-of-day measurements and a reference temperature curve. Agron. J., 96(6), 1553-1561. https://doi.org/10.2134/agronj2004.1553

Peters, R. T., \& Evett, S. R. (2004b). Complete center pivot automation using the temperature-time threshold method of automatic irrigation scheduling. ASAE Paper No. 042196. St. Joseph, MI: ASAE. https://doi.org/10.13031/2013.16409

Peters, R. T., \& Evett, S. R. (2005). Using low-cost GPS receivers for determining field position of mechanized irrigation systems. Appl. Eng. Agric., 21(5), 841-845. https://doi.org/10.13031/2013.19711

Peters, R. T., \& Evett, S. R. (2006). A fully automated center pivot using crop canopy temperature: Preliminary results. Proc. USCID Water Mgmt. Conf. Groundwater and Surface Water under Stress (pp. 139-148). Denver, CO: U.S. Committee on Irrigation and Drainage. Retrieved from https://mountainscholar.org/bitstream/handle/10217/46560/115 Proceedings $\% 202006 \% 20$ USCID $\% 20$ Boise $\% 20$ Peters.pdf? sequ ence $=14$ 
Peters, R. T., \& Evett, S. R. (2008). Automation of a center pivot using the temperature-time-threshold method of irrigation scheduling. J. Irrig. Drain. Eng., 134(3), 286-291. https://doi.org/10.1061/(ASCE)0733-9437(2008)134:3(286)

Schwartz, R. C., Evett, S. R., Anderson, S. K., \& Anderson, D. J. (2016). Evaluation of a direct-coupled time-domain reflectometry for determination of soil water content and bulk electrical conductivity. Vadose Zone J., 15(1). https://doi.org/10.2136/vzj2015.08.0115

Shi, J., Li, S., Zuo, Q., \& Ben-Gal, A. (2015). An index for plant water deficit based on root-weighted soil water content. $J$. Hydrol., 522, 285-294. https://doi.org/10.1016/j.jhydrol.2014.12.045

Stone, K., Bauer, P., O’Shaughnessy, S., Andrade, A., \& Evett, S. (2019). A variable-rate irrigation decision support system for corn in the U.S. eastern coastal plain. In J. V. Stafford (Ed.), Proc. 12th European Conf. on Precision Agric. (pp. 673-679). Wageningen, The Netherlands: Wageningen Academic. https://doi.org/10.3920/978-90-8686-888-9_83

Taghvaeian, S., Comas, L., DeJonge, K. C., \& Trout, T. J. (2014). Conventional and simplified canopy temperature indices predict water stress in sunflower. Agric. Water Mgmt., 144, 69-80. https://doi.org/10.1016/j.agwat.2014.06.003

Upchurch, D. R., \& Mahan, J. R. (1988). Maintenance of constant leaf temperature by plants: II. Experimental observations in cotton. Environ. Exp. Bot., 28(4), 359-366. https://doi.org/10.1016/0098-8472(88)90060-3

Upchurch, D. R., Wanjura, D. F., Burke, J. J., \& Mahan, J. R. (1996). Biologically identified optimal temperature interactive console (BIOTIC) for managing irrigation. U.S. Patent No. $5,539,637$.

USDA-NASS. (2019). 2018 Irrigation and Water Management Survey. Special Studies, Part 1 (AC-17-SS-1). Washington, DC: USDA National Agricultural Statistics Service.

Vories, E., O'Shaughnessy, S. A., \& Andrade, M. (2019). Comparison of precision and conventional irrigation management of cotton. In J. V. Stafford (Ed.), Proc. 12th European Conf. on Precision Agric. (pp. 695-702). Wageningen, The Netherlands: Wageningen Academic. https://doi.org/10.3920/978-90-8686-888-9_86

Vories, E., Sudduth, K., Evett, S., O'Shaughnessy, S. A., \& Andrade, A. (2017). Comparison of crop stress and soil maps to enhance variable-rate irrigation prescriptions. Proc. 7th AsianAustralasian Conf. on Precision Agriculture. Auckland, New Zealand: New Zealand Technology Industry Association (NZTech). http://doi.org/10.5281/zenodo.893704

Walker, G. K., \& Hatfield, J. L. (1979). Test of the stress-degreeday concept using multiple planting dates of red kidney beans. Agron. J., 71(6), 967-971. https://doi.org/10.2134/agronj1979.00021962007100060019x

Wanjura, D. F., Upchurch, D. R., \& Mahan, J. R. (1990). Evaluating decision criteria for irrigation scheduling of cotton. Trans. ASAE, 33(2), 512-518. https://doi.org/10.13031/2013.31359

Wanjura, D. F., Upchurch, D. R., \& Mahan, J. R. (1992). Automated irrigation based on threshold canopy temperature. Trans. ASAE, 35(5), 1411-1417. https://doi.org/10.13031/2013.28748

Wanjura, D. F., Upchurch, D. R., \& Mahan, J. R. (1995). Control of irrigation scheduling using temperature-time thresholds. Trans. ASAE, 38(2), 403-409. https://doi.org/10.13031/2013.27846

Wanjura, D. F., Upchurch, D. R., Hatfield, J. L., Burke, J. J., \& Mahan, J. R. (1988). Cotton irrigation using the "thermal kinetic window" criteria. In J. M. Brown (Ed.), Proc. Beltwide Cotton Prod. Res. Conf. (pp. 183-185). Memphis, TN: National Cotton Council.

Wu, X., Zhang, W., Liu, W., Zuo, Q., Shi, J., Yan, X., ... Ben-Gal, A. (2017). Root-weighted soil water status for plant water deficit index based irrigation scheduling. Agric. Water Mgmt., 189, 137-147. https://doi.org/10.1016/j.agwat.2017.04.013 